\title{
Choice of sites for study of slit skin smears
}

\author{
SURRINDER KAUR, B KUMAR \& H DARSHAN \\ Post-Graduate Institute of Medical Education and \\ Research, Chandigarh, India
}

Received for publication 28 August 1980

\begin{abstract}
Summary In view of recent publications drawing attention to the importance of fingers and toes as sites for slit skin smears in leprosy, a study has been carried out on patients in India to compare the bacterial load and morphology of bacilli at various sites in both treated and untreated lepromatous patients. Although the ear lobes gave maximum bacteriological and morphological indices in most instances, a few cases gave higher values at elbows, fingers and toes. In three patients, bacilli could be detected only from sites other than ear lobes. The importance of taking slit skin smears from peripheral sites, including fingers and toes, is stressed.
\end{abstract}

\section{Introduction}

The bacteriological status of leprosy patients is usually assessed by the slit skin smear method of Wade $(1963)^{1}$ as described by Cochrane (1964). ${ }^{2}$ The bacterial index (BI) is used as a semiquantitative index for the assessment of bacterial load. Morphological index (MI) is still assumed to be a sensitive index for assessment of chemotherapeutic efficacy and detection of bacterial resistance. Skin slit smears from various sites have been used by different workers for diagnosis, assessment of drug therapy and early detection of drug resistance. With the increasing importance of drug resistance, to obtain a meaningful result there is a real need for standardization of methods of assessment of drug effectiveness including the simplest available method of slit skin smears. Although serial biopsies have been recommended for the assessment of bacteriological changes (Leiker, 1971) $)^{3}$ for patients on therapy, the slit skin smear method has been shown to be sensitive enough for bacteriological and morphological changes (Izumi, 1971). ${ }^{4}$ Various sites have been recommended by different workers and the number suggested varies from one to eleven sites. In spite of all its limitations, MI still remains the only method for routine estimation of viability of Mycobacterium leprae in skin slit smears. 
Ridley et al (1976) $)^{5}$ have reported highest BI and MI from smears taken from fingers. Fingers were also stressed to be the important site for picking up solid staining bacilli in long-standing treated lepromatous cases when other sites may be bacteriologically negative (Jopling et al, 1979). ${ }^{6}$ The present study was undertaken to compare the bacterial load (BI) and their morphology (MI) at various sites in treated and untreated lepromatous patients and to find out the site, which in addition to conventional sites, yielded more bacilli and for a longer time under treatment. Besides the fingers, toes were also included to see if this could provide the same or more information than that obtained from fingers alone.

\section{Material and methods}

Forty patients with lepromatous leprosy, irrespective of age and sex, attending the leprosy clinic of the Postgraduate Institute of Medical Education and Research, Chandigarh, India, were taken up for the study. There were twenty each in the treated and untreated groups. All untreated patients were taken for the study irrespective of the duration of the disease. All treated patients had taken treatment with only dapsone for a duration of 5-9 years. Almost all the patients either wore 'chappals' (footwear with almost whole of dorsum of foot and toes exposed) or nothing at all.

Skin slit smears were taken from both ear lobules, both elbows and dorsum of middle phalanges of the middle finger/toe of both hands/feet (terminal phalanges were not taken because many patients had almost total resorption/ ulceration especially of the toes) and if the middle finger/toe was missing adjoining finger/toe was taken. The slides were stained with Ziehl-Neelsen method. Bacteriological index (BI) was estimated according to the method of Ridley (1964) ${ }^{7}$ and morphological index (MI) according to the method of Waters and Rees (1962). ${ }^{8}$ The slides were studied by at least two observers without being aware of the previous bacteriological status and the site. Any gross discrepancy was rechecked by taking fresh smears and in the case of minor discrepancies (MI only), the mean of two figures was taken.

\section{Results}

The results are given in Table 1.

Bacteriological index (BI) of untreated patients:

(1) Ear lobes gave uniformally higher values as compared to those from elbows (higher in 13).

(2) Ear lobes gave values which were higher as compared to those from fingers (higher in 16). 
Table 1. BI and MI at various sites in treated and untreated lepromatous patients

\begin{tabular}{|c|c|c|c|c|c|c|c|c|c|c|}
\hline $\begin{array}{l}\mathrm{Sr} \\
\mathrm{No}\end{array}$ & Name & $\begin{array}{l}\text { Age \& } \\
\text { Sex }\end{array}$ & $\begin{array}{l}\text { Rt EL } \\
\text { BI MI }\end{array}$ & $\begin{array}{l}\text { Lt EL } \\
\text { BI MI }\end{array}$ & $\begin{array}{l}\text { Rt Elb } \\
\text { BI MI }\end{array}$ & $\begin{array}{l}\text { Lt Elb } \\
\text { BI MI }\end{array}$ & $\begin{array}{l}\text { Rt Fing } \\
\text { BI MI }\end{array}$ & $\begin{array}{l}\text { Lt Fing } \\
\text { BI MI }\end{array}$ & $\begin{array}{l}\text { Rt toe } \\
\text { BI MI }\end{array}$ & $\begin{array}{l}\text { Lt toe } \\
\text { BI MI }\end{array}$ \\
\hline 1 & HS & $49 \mathrm{M}$ & $2+26 \%$ & $1+\mathrm{NP}$ & $3+13 \%$ & -- & $1+\mathrm{NP}$ & $-\quad-$ & $-\quad-$ & $-\quad-$ \\
\hline 2 & JK & $45 \mathrm{~F}$ & $5+3 \%$ & $6+3 \%$ & $4+2 \%$ & $4+\quad 3 \%$ & $4+5 \%$ & $4+6 \%$ & $4+5 \%$ & $4+\quad 4 \%$ \\
\hline 3 & $\mathrm{RC}$ & $36 \mathrm{M}$ & $5+4 \%$ & $5+4 \%$ & $4+3 \%$ & $4+5 \%$ & $3+8 \%$ & $2+7 \%$ & $4+10 \%$ & $4+8 \%$ \\
\hline 4 & AS & $45 \mathrm{M}$ & $4+10 \%$ & $4+8 \%$ & $4+\quad 4 \%$ & $3+\quad 3 \%$ & $1+\mathrm{NP}$ & $1+\mathrm{NP}$ & $1+\mathrm{NP}$ & $1+\mathrm{NP}$ \\
\hline 5 & GD & $45 \mathrm{~F}$ & $4+12 \%$ & $4+11 \%$ & $5+14 \%$ & $3+16 \%$ & $1+\mathrm{NP}$ & $3+10 \%$ & $2+8 \%$ & $1+N P$ \\
\hline 6 & RD & $30 \mathrm{~F}$ & $2+25 \%$ & $1+\mathrm{NP}$ & $3+26 \%$ & $1+\mathrm{NP}$ & $2+20 \%$ & $1+\mathrm{NP}$ & -- & $-\quad-$ \\
\hline 7 & $\mathrm{~L}$ & $25 \mathrm{~F}$ & $4+27 \%$ & $4+25 \%$ & $4+47 \%$ & $4+38 \%$ & $3+32 \%$ & $4+27 \%$ & $4+26 \%$ & $4+34 \%$ \\
\hline 8 & PD & $32 \mathrm{M}$ & $4+2 \%$ & $4+3 \%$ & $2+1 \%$ & $3+1 \%$ & $1+\mathrm{NP}$ & $1+\mathrm{NP}$ & $1+N P$ & $3+1 \%$ \\
\hline 9 & BS & $70 \mathrm{M}$ & $2+2 \%$ & $1+\mathrm{NP}$ & $2+3 \%$ & $1+N P$ & $1+N P$ & $1+N P$ & $-\quad-$ & $-\quad-$ \\
\hline 10 & MR & $38 \mathrm{M}$ & $5+2 \%$ & $5+2 \%$ & $3+5 \%$ & $5+5 \%$ & $3+6 \%$ & $3+8 \%$ & $3+3 \%$ & $3+4 \%$ \\
\hline 11 & SS & $50 \mathrm{M}$ & $2+10 \%$ & $2+7 \%$ & $2+12 \%$ & $1+N P$ & $1+\mathrm{NP}$ & $1+\mathrm{NP}$ & -- & -- \\
\hline 12 & RR & $46 \mathrm{M}$ & $4+16 \%$ & $4+21 \%$ & $3+18 \%$ & $3+15 \%$ & $4+24 \%$ & $4+26 \%$ & $2+14 \%$ & $2+25 \%$ \\
\hline 13 & $\mathrm{MC}$ & $25 \mathrm{M}$ & $2+8 \%$ & $1+N P$ & $1+N P$ & $1+\mathrm{NP}$ & $1+\mathrm{NP}$ & $1+\mathrm{NP}$ & $1+\mathrm{NP}$ & $1+\mathrm{NP}$ \\
\hline 14 & $\mathrm{~K}$ & $18 \mathrm{~F}$ & $3+8 \%$ & $3+\quad 6 \%$ & $1+N P$ & $2+5 \%$ & $1+\mathrm{NP}$ & $1+N P$ & $1+\mathrm{NP}$ & $1+\mathrm{NP}$ \\
\hline 15 & $\mathrm{P}$ & $37 \mathrm{M}$ & $3+52 \%$ & $3+50 \%$ & $4+20 \%$ & $4+18 \%$ & $4+18 \%$ & $4+16 \%$ & $4+20 \%$ & $4+16 \%$ \\
\hline 16 & MP & $40 \mathrm{M}$ & $3+1 \%$ & $2+1 \%$ & $2+3 \%$ & $1+\mathrm{NP}$ & $1+\mathrm{NP}$ & $1+\mathrm{NP}$ & $1+\mathrm{NP}$ & $1+\mathrm{NP}$ \\
\hline 17 & $\mathrm{H}$ & $28 \mathrm{M}$ & $6+26 \%$ & $5+28 \%$ & $4+29 \%$ & $3+34 \%$ & $3+30 \%$ & $3+31 \%$ & $4+28 \%$ & $4+29 \%$ \\
\hline 18 & UK & $29 \mathrm{M}$ & $4+\quad 0 \%$ & $4+\quad 0 \%$ & $3+1 \%$ & $3+1 \%$ & $2+4 \%$ & $2+5 \%$ & $4+\quad 0 \%$ & $4+\quad 0 \%$ \\
\hline 19 & $\mathrm{PC}$ & $34 \mathrm{M}$ & $3+5 \%$ & $3+5 \%$ & $4+10 \%$ & $1+\mathrm{NP}$ & $1+\mathrm{NP}$ & $1+\mathrm{NP}$ & $1+N P$ & $1+\mathrm{NP}$ \\
\hline 20 & HS & $49 \mathrm{M}$ & $2+8 \%$ & $1+\mathrm{NP}$ & $3+7 \%$ & $1+\mathrm{NP}$ & $-\quad-$ & $-\quad-$ & $3+3 \%$ & $1+\mathrm{NP}$ \\
\hline 21 & JK & $50 \mathrm{~F}$ & $-\quad-$ & $-\quad-$ & $1+N P$ & $-\quad-$ & $-\quad-$ & -- & $-\quad-$ & -- \\
\hline 22 & GP & $38 \mathrm{M}$ & $1+N P$ & $1+N P$ & $1+\mathrm{NP}$ & $2+\quad 6 \%$ & $1+\mathrm{NP}$ & $1+\mathrm{NP}$ & $1+\mathrm{NP}$ & $1+\mathrm{NP}$ \\
\hline 23 & PNJ & $68 \mathrm{M}$ & $-\quad-$ & $-\quad-$ & $-\quad-$ & $1+\mathrm{NP}$ & $-\quad-$ & $-\quad-$ & $1+\mathrm{NP}$ & $-\quad-$ \\
\hline 24 & S & $42 \mathrm{M}$ & $1+N P$ & $1+\mathrm{NP}$ & $1+\mathrm{NP}$ & $1+\mathrm{NP}$ & $1+\mathrm{NP}$ & $1+\mathrm{NP}$ & $1+\mathrm{NP}$ & $1+\mathrm{NP}$ \\
\hline 25 & SR & $25 \mathrm{M}$ & $1+\mathrm{NP}$ & $2+\quad 6 \%$ & $1+\mathrm{NP}$ & $1+\mathrm{NP}$ & $1+\mathrm{NP}$ & $1+\mathrm{NP}$ & $-\quad-$ & $-\quad-$ \\
\hline 26 & G & $35 \mathrm{M}$ & $1+\mathrm{NP}$ & $1+\mathrm{NP}$ & $-\quad-$ & $-\quad-$ & $1+\mathrm{NP}$ & $1+\mathrm{NP}$ & - & - \\
\hline
\end{tabular}


Table 1. BI and MI at various sites in treated and untreated lepromatous patients (continued)

\begin{tabular}{|c|c|c|c|c|c|c|c|c|c|c|}
\hline $\begin{array}{l}\text { Sr } \\
\text { No }\end{array}$ & Name & $\begin{array}{l}\text { Age \& } \\
\text { Sex }\end{array}$ & $\begin{array}{l}\text { Rt EL } \\
\text { BI MI }\end{array}$ & $\begin{array}{l}\text { Lt EL } \\
\text { BI MI }\end{array}$ & $\begin{array}{l}\text { Rt Elb } \\
\text { BI MI }\end{array}$ & $\begin{array}{l}\text { Lt Elb } \\
\text { B I MI }\end{array}$ & $\begin{array}{l}\text { Rt Fing } \\
\text { B I MI }\end{array}$ & $\begin{array}{l}\text { Lt Fing } \\
\text { BI MI }\end{array}$ & $\begin{array}{l}\text { Rt toe } \\
\text { BI MI }\end{array}$ & $\begin{array}{l}\text { Lt toe } \\
\text { B I MI }\end{array}$ \\
\hline 27 & RS & $50 \mathrm{M}$ & $1+\mathrm{NP}$ & $1+\mathrm{NP}$ & - & - & $-\quad-$ & $-\quad-$ & - & $-\quad-$ \\
\hline 28 & $\mathrm{~K}$ & $30 \mathrm{~F}$ & -- & - & -- & - & $1+\mathrm{NP}$ & - & - & -- \\
\hline 29 & SD & $36 \mathrm{~F}$ & $1+\mathrm{NP}$ & $3+12 \%$ & $-\quad-$ & $-\quad-$ & $-\quad-$ & $-\quad-$ & - & $-\quad-$ \\
\hline
\end{tabular}

Patients No 30 to 40: No bacilli could be seen at any of the above-mentioned sites, hence not charted.

Patients No 1-20: Untreated; 21-40: Treated.

EL - Ear lobule; Elb - Elbow; Fing - Finger; NP - MI not possible. 
(3) Ear lobule values were consistently higher than those obtained from toes (higher in 16).

Morphological index (MI) of untreated patients:

(1) Ear lobules showed higher number of solid staining bacilli than those seen in smears from elbows (higher in 10, lower in 8).

(2) Ear lobules gave higher MI values than those from fingers (higher in 13 and lower in 7).

(3) Ear lobules gave values for MI which were higher than those seen in smears from toes (higher in 13).

Bacteriological index (BI) of treated patients:

(1) No bacilli could be detected at any of the sites mentioned above in eleven patients.

(2) Out of the other nine, maximum number (6) showed bacilli in the ear lobules followed by fingers (5), elbows (4) and toes (3).

(3) In three patients bacilli could be detected from sites other than ear lobules (elbows -2 , fingers -1 , and toes -1 ; one patient gave positive results from elbows and toes).

Morphological index (MI) of treated patients.

(1) Except in three situations (Elbow-1, Ear lobules-2) the bacilli were too scanty to enable counting.

(2) Solid and fragmented bacilli were seen almost equally from all the sites wherever the smears were positive.

\section{Discussion}

It is evident from the results that BI and MI values were generally higher in the ear lobules in untreated as well as treated patients. There were, however, occasions where the BI and MI were higher at elbows, fingers and toes, especially in untreated lepromatous patients. At least in treated patients, where the MI was zero from ear lobules, solid staining bacilli could be detected from elbows and fingers.

The ear lobules uniformally showed bacilli more frequently than the other sites, but the differences were more significant in three (16.6\%) long-treated patients, in whom no bacilli could be detected in the ear lobules, but were detectable from other sites like elbows, fingers and toes. The percentage though small is significant in relation to patients on long-term follow-up for the assessment of therapeutic response and discovery of resistant strains.

There is no uniformity of opinion regarding the selection and number of sites for demonstration of bacilli. One to eleven sites have been recommended by various workers (Davison, 1961;9 Dharmendra, 1967;10 Browne, 1959;11 
1966; 12 1967:13 Leiker and Carling, 1969;14 Garrod and Ellard, 1968; ${ }^{15}$ Cochrane, 1964; ${ }^{2}$ Bryceson and Pfaltzgraff, 1973;16 Levy, 1969;17 Jopling, 1971). ${ }^{18}$ Levy (1969), ${ }^{17}$ however, observed wide variation both in BI and MI from different sites.

Ears were found to have the higher BI followed by nearly similar results for buttocks in males and thighs in females. Arm, chest and back have been shown to have the lowest BI (Gideon and Job, 1965:19 Padma, 1965). ${ }^{20}$ Recently Ahmed et al (1979) ${ }^{21}$ found higher BI from ear lobes, buttocks, face, fingers and toes whereas legs, arms and back were found to have the lowest BI. MI was found to be correspondingly high where BI was more. In a similar study, Kaur et al (to be published) ${ }^{22}$ found higher BI and $\mathrm{MI}$ in ear lobes and fingers as compared to that from knees and elbows. Hiramalini et al (1978) ${ }^{23}$ found fingers and uncovered toes to be the most productive sites, even better than ear lobules. The present study for untreated and treated lepromatous patients confirms the findings of Gideon and Job (1965), ${ }^{19}$ Padma (1965) ${ }^{20}$ and Ahmed et al (1979), ${ }^{21}$ in showing that ear lobules have the maximum BI and MI as compared to the other sites, except in isolated cases where elbows, fingers and toes gave marginally higher values. In eleven out of the twenty longtreated patients, no bacilli could be detected at any site. In the remaining nine, in whom bacilli were demonstrated, ear lobules were positive in six followed by elbows, fingers and toes. In three patients, bacilli could be detected only from sites other than the ear lobes.

On the basis of the above observations it is recommended that in addition to the standard ear lobe smears it is rational and essential to study multiple sites including the peripheral sites like fingers and toes. This has been previously recommended (Hiramalini et al, 1978;23 Ahmed et al, 1979;21 Jopling et al, 1979; ${ }^{6}$ Ridley et al, 1976). ${ }^{5}$

Why do bacilli remain viable in the peripheral areas? We consider that there is more to it than the coolness of the parts only. A lower drug concentration consequent to various peripheral vascular abnormalities (Kaur et al, 1976) ${ }^{24}$ may be the reason for persistence of bacilli. The inclusion of superficial cutaneous twigs in the slit on the dorsal aspects of fingers and toes may theoretically improve the chances of finding the bacilli at these sites. All this, however, should not detract from the importance of studying multiple sites, which are essential to reveal any persistent bacilli in the skin.

\section{References}

1 Wade HW. The examination of skin lesions for bacilli. Int J Lepr 1963, 31, 240.

2 Cochrane RG. Technique of examination. In: Cochrane RG, Davey TF, eds. Leprosy in Theory and Practice. 2nd ed. Bristol: John Wright and Sons, 1964, p. 612.

3 Leiker DL. Assessment of bacteriological changes in leprosy based on serial biopsies. Lepr Rev, 1971, 42; 121. 
${ }^{4}$ Izumi S. Statistical calculations of the confidence interval and significant difference ranges of the morphologic index. Int J Lepr, 1979, 39, 852.

${ }^{5}$ Ridley MJ, Jopling WH, Ridley DS. Acid fast bacilli in the fingers of long treated lepromatous patients. Lepr Rev, 1976, 47, 93.

${ }^{6}$ Jopling WH, Rees RJW, Ridley DS, Ridley MJ, Samuel NM. The fingers as sites of leprosy bacilli in pre-relapse patients. Lepr Rev, 1979, 50, 289.

${ }^{7}$ Ridley DS. Bacterial indices. In: Cochrane RG, Davey TF, eds. in: Leprosy in Theory and Practice. Bristol: John Wright and Sons, 1964, p. 620.

${ }^{8}$ Waters MFR, Rees RJW. Changes in the morphology of M. leprae in patients under treatment. Int J Lepr 1962, 30, 266.

${ }_{9}^{9}$ Davison AR. Six year follow up of diphenyl thiourea treatment. Lepr Rev 1961, 36, 145.

10 Dharmendra. Notes on leprosy. Ministry of Health, Govt. of India, 1967, p. 254.

11 Brown SG. Some observations of the bacteriological index in lepromatous leprosy. Lepr Rev 1959, 30, 1974.

12 Brown SG. Some observations on the morphological index in lepromatous leprosy. Int $J$ Lepr 1966, 34, 23.

13 Brown SG. Drug trials in leprosy. Some unemphasized factors. Lepr Rev 1967, 38, 7.

14 Leiker DL, Carling D. Second trial of low dosage of DDS in lepromatous leprosy. Lep Rev, 1969, 40, 54.

15 Garrod JMB, Ellard GA. Appearance of resistance during prolonged treatment of leprosy with thiam butosine. Lepr Rev, 1968, 39, 113.

16 Bryceson A, Pfaltzgraff RE. Leprosy for students of medicine. Churchill Livingstone, 1973, p. 32.

17 Levy L. Uniformity of the solid ratio of Mycobacterium leprae from lesion to lesion. Int $J$ Lepr, 1969, 37, 416.

18 Jopling WH. Handbook of leprosy. Heinemann, 1971.

19 Gideon H, Job CK. Skin smears in leprosy. Lepr India, 1965, 37, 74.

20 Padma MN. Choice of sites for routine smearing. Lepr India 1965, 37, 87.

21 Ahmed HA, Belehu A, Stoner G, Touw J, Atlaw T. Selection of sites for slit skin smears. Lepr Rev, 1979, 50, 283.

${ }^{22}$ Kaur S, Kumar B, Darshan H, Singh S. Choice of skin slit smears for study of bacterial and morphological indices (to be published).

${ }^{23}$ Hiramalini S, Joseph NA, Chako CJG. Concentration and persistance of bacilli in the fingers and toes of patients with lepromatous leprosy. Lepr Rev, 1978, 49, 223.

${ }^{24}$ Kaur S, Wahi PL, Chakravarti RN, Sodhi JS, Vadhwa MB, Khera AS. Peripheral vascular deficit in leprosy. Int J Lepr, 1976, 44, 332. 